\title{
ASSESSMENT
}

\section{Development and Assessment of an Undergraduate Research Program at a Two-Year, Rural, Hispanic-Serving Institution: The Essential Role of Partnerships}

Matthew R. Loeser, Makaylah Newkirk, Yakima Valley College

Kara I. Gabriel, Audrey D. Huerta, Central Washington University

\begin{abstract}
Yakima Valley College - a two-year, Hispanic-serving institution in south-central Washington state-partnered with four-year universities, agricultural centers, businesses, and federal and state agencies to develop a streamlined undergraduate research experience in which students work closely with a faculty mentor in a science, technology, engineering, or mathematics (STEM) field on summer projects of 120 hours each. Assessment metrics reveal high transfer, graduation, and/or continued enrollment rates for research participants as well as increased student perceptions in thinking and working like a scientist, personal gains related to research work, and skills. Faculty also benefited as indicated by high rates of return to the program. This article reviews the importance of multiple stakeholders in program development, including the essential role of university and community partnerships.
\end{abstract}

Keywords: community colleges, student outcomes, undergraduate research, university partnerships

doi: 10.18833/spur/4/3/10

Community colleges play an essential role in the rate of bachelor's degree attainment, as 52 percent of the graduates who earned their first bachelor's degree between 2008 and 2017 had attended a community college at some point in their college career (Foley, Milan, and Hamrick 2020). Community colleges have an even stronger role in serving traditionally underrepresented minority (URM) groups (Dinh and Zhang 2020). URMs (including Hispanics or Latinos, Blacks or African Americans, Native Hawaiian or other Pacific Islander, and those reporting more than one ethnicity) were all more likely than whites to have attended a community college in the 2008-2017 period (Foley, Milan, and Hamrick 2020). Thus, community colleges are poised to offer opportunities for URMs in science, technology, engineering, and mathematic (STEM) fields (Cohen and Brawer 2014; Van Noy and Zeidenberg 2017), with the community college transfer pathway providing an affordable education avenue for students who otherwise may not have access to STEM degree programs (Dinh and Zhang 2020; Mooney and Foley 2011).

Community colleges are already essential in producing STEM graduates, and the number of students choosing a community college STEM pathway is growing. From 1999 to 2008, the percentage of recent STEM graduates at the bachelor's and master's levels who had attended a community college increased from 41 percent to 46 percent (National Science Board 2012). Unfortunately, although nearly 80 percent of first-time community college students begin with the goal of earning a bachelor degree or a higher-level credential (Horn and Skomsvold 2011), these students have a lower probability of success than those who begin at four-year institutions (Bahr et al. 2013; Wang 2015), perhaps because of challenges in building academic momentum in community college settings (Attewell, Heil, and Reisel 2012).

One high-impact practice that increases the likelihood of perseverance of both STEM and URM students is a mentored undergraduate research experience (URE; Dinh and Zhang 2020; Eagan et al. 2013; Hernandez et al. 2013; Russell, Hancock, and McCullough 2007). Among the multitude of reported benefits, UREs help clarify interests in STEM careers, increase confidence in research skills 
and expectations of obtaining a $\mathrm{PhD}$, as well as resulting in gains in independence, intrinsic motivation to learn, and active participation in subsequent courses, particularly for transfer and URM students (Carpi et al. 2016; Dinh and Zhang 2020; Espinosa 2011; Graham et al. 2013; Lopatto 2017; Russell, Hancock, and McCullough 2007). A faculty-mentored URE can also enhance transfer students' academic and social adjustment to four-year institutions (Lopez and Jones 2017).

Given their positive impacts, UREs at community colleges could serve to improve retention of URMs in STEM by addressing lagging interest in STEM fields and providing meaningful preparation for research at four-year institutions (Goldrick-Rab 2010). Unfortunately, UREs at community colleges remain rare despite National Science Foundation (NSF) funding to support UREs at primarily undergraduate institutions. For example, over 27 years of NSF Research Experiences for Undergraduate award funding, only about 2 percent of recipients were associate-level institutions (Barney 2017). The low rate of UREs at community colleges represents a lost opportunity for students and for improving the STEM pipeline to four-year institutions. The cost of this lost opportunity is further magnified by the demographic reality that, as previously noted, nearly half of all undergraduates attend a community college at some point in their college career, and most of these students are URMs or from low-income backgrounds (Ma and Baum 2016).

One method of overcoming potential barriers to creating URE programs at community colleges is to form collaborations between two- and four-year institutions. For example, both Barber and colleagues (2020) and Hirst and colleagues (2014) undertook five-year partnerships in suburban-urban communities (i.e., two Hispanic-serving institutions [HSIs] in the Houston area and a partnership in southeastern Massachusetts, respectively) in which community college students were placed on research teams either led by or co-mentored by faculty at the four-year institution. This article presents an overview of an eightyear effort to establish a URE at a two-year HSI in a primarily rural, agricultural area. Like Barber and colleagues (2020) and Hirst and colleagues (2014), the role of partnerships, particularly with regional four-year institutions, was essential in the development of the program discussed here. However, in contrast to the previously cited programs, the majority of student and faculty participants in the current program conducted their research independent of partner four-year institutions.

\section{Research Program Structure, Funding, and Assessment}

\section{College Context}

Yakima Valley College (YVC) is a two-year college located in the agricultural region of south-central Washington state with a full-time enrollment of approximately
4,000 students. One-third of the students seek two-year transfer degrees. YVC's student population is 83 percent first-generation and 71 percent low-income-percentages that exceed the national average for public two-year institutions. With the region's history of intensification of agriculture, the Hispanic student population has grown to 60 percent, and the institution has maintained federal designation as an HSI since 2002. More than 95 percent are commuter students living in the immediate urban area of Yakima or in the rural valleys that extend from the city center. Students intending to pursue a STEM degree at a four-year institution enroll at YVC to complete their first- and second-year general education courses; they are designated STEM Pathway students and complete general education requirements as well as multi-quarter course sequences in the sciences and mathematics.

\section{YVC's Summer Undergraduate Research Experience (SURE)}

The YVC SURE program has developed within a context in which the students and faculty have limited time and resources to contribute to a research experience. In contrast to participants in longer, more intensive UREs offered at four-year institutions, students and faculty in the YVC SURE program commit 120 hours to a project that lasts from three to seven weeks in the summer. Faculty develop single-summer projects or mentor individualized segments of multiyear projects. Each project usually has one mentor and two students. Research during the academic year is exceedingly rare; the faculty teach full time with no contractual research expectations. YVC has approximately 30 STEM faculty with core disciplines that include biology, chemistry, computer science, engineering, geosciences, mathematics, nutrition, psychology, and physics. The majority of SURE students are secondyear students, although first-year students are eligible to participate in the program. Over the program's length, 194 students have been enrolled (see Table 1). From 2012 to 2019 , students earned a $\$ 1500$ stipend, whereas faculty received a $\$ 3000$ stipend; in 2020, the student stipend was increased to $\$ 1725$.

\section{YVC SURE Program Funding Sources}

Funding for the program was initially provided in 2011 by an HSI STEM grant from the Department of Education to Heritage University, a four-year private university on the Yakama Indian Reservation that is approximately 20 miles from YVC. The grant included funds for partnering with YVC to support experiential learning in STEM. Over the five years of that grant, the YVC SURE program was managed by Heritage University with YVC's role expanding from initial identification and recruitment of participating faculty and students to a shared partnership in which YVC managed the growing number of student applications and established standardized goalposts and curriculum, including a requirement of research posters as an end-of-project 
TABLE 1. YVC SURE Student and Faculty Information

\begin{tabular}{|c|c|c|c|c|c|}
\hline Program year & $\begin{array}{l}\text { Student } \\
\text { number }\end{array}$ & $\begin{array}{c}\text { Student } \\
\text { demographics }\end{array}$ & $\begin{array}{c}\text { Student } \\
\text { success rate }^{\mathrm{a}}\end{array}$ & $\begin{array}{c}\text { Project } \\
\text { disciplines }\end{array}$ & $\begin{array}{l}\text { Returning faculty as } \\
\text { a proportion of all } \\
\text { faculty }\end{array}$ \\
\hline 2012 & 6 & No data ${ }^{b}$ & No data ${ }^{b}$ & Biology, Chemistry & - \\
\hline 2013 & 10 & No data ${ }^{b}$ & No data ${ }^{b}$ & Biology, Chemistry & 3 of 4 \\
\hline 2014 & 15 & No data ${ }^{b}$ & No data ${ }^{b}$ & Biology, Chemistry & 4 of 5 \\
\hline 2015 & 18 & $\begin{array}{l}42 \% \text { women; } \\
38 \% \text { URM }\end{array}$ & $88 \%$ & $\begin{array}{l}\text { Biology, Chemistry, } \\
\text { Mathematics }\end{array}$ & 3 of 6 \\
\hline 2016 & 24 & $\begin{array}{l}33 \% \text { women; } \\
45 \% \text { URM }\end{array}$ & $100 \%$ & $\begin{array}{c}\text { Biology, Chemistry, } \\
\text { Engineering, Mathematics, } \\
\text { Physics }\end{array}$ & 6 of 12 \\
\hline 2017 & 35 & $\begin{array}{l}46 \% \text { women; } \\
47 \% \text { URM }\end{array}$ & $83 \%$ & $\begin{array}{l}\text { Agriculture, Biology, } \\
\text { Chemistry, Engineering, } \\
\text { Mathematics, Nutrition, } \\
\text { Psychology }\end{array}$ & 7 of 15 \\
\hline 2018 & 31 & $\begin{array}{l}55 \% \text { women; } \\
43 \% \text { URM }\end{array}$ & $84 \%$ & $\begin{array}{l}\text { Biology, Chemistry, } \\
\text { Engineering, Geology, } \\
\text { Mathematics, Nutrition, } \\
\text { Physics, Psychology }\end{array}$ & 12 of 16 \\
\hline 2019 & 30 & $\begin{array}{l}48 \% \text { women; } \\
48 \% \text { URM }\end{array}$ & $83 \%$ & $\begin{array}{l}\text { Biology, Chemistry, } \\
\text { Engineering, Geology, } \\
\text { Mathematics, Nutrition, } \\
\text { Physics, Psychology }\end{array}$ & 15 of 15 \\
\hline 2020 & 25 & $\begin{array}{l}48 \% \text { women; } \\
64 \% \text { URM }\end{array}$ & $88 \%$ & $\begin{array}{c}\text { Agriculture, Biology, Computer } \\
\text { Sciences, Mathematics, } \\
\text { Nutrition, Physics }\end{array}$ & 9 of 10 \\
\hline
\end{tabular}

Note: a Student Success Rate refers to the percentage of students who are still enrolled at YVC, have graduated and/or have transferred to a four-year institution.

${ }^{\mathrm{b}}$ As the SURE program was managed by an external university partner, student-level records were not obtainable.

deliverable, an end-of-program symposium for students to present their work, and student enrollment in a research credit so that liability could be managed and the experience could be formally documented on student transcripts.

In 2016, YVC received NSF S-STEM and Department of Education HSI STEM grants to continue research funding and create a full-time STEM director position that included management of undergraduate research. Expansion of the YVC SURE program was further enabled by a partnership with Central Washington University, a four-year public regional emerging HSI approximately 40 miles from YVC. The partnership with the university included funding for several YVC student and faculty stipends as well as funds to incentivize Central Washington University faculty to share their research facilities and lead activities with YVC students, including instruction in new laboratory techniques. Additional monies were provided by a regional consortium funded by NSF's Louis Stokes Alliances for Minority Participation. Although student and faculty stipends were prioritized, activities also were funded such as weekly "Science \& Pizza" seminars where guest speakers presented on STEM-related topics to enhance the research experience and promote cohort cohesion.

\section{SURE Program Assessment Methodology and Results}

Program growth was substantial for both students and faculty, and student demographic information indicates that 38-64 percent of YVC's SURE participants were URMs (see Table 1). Student success rate, defined as the percentage of students still enrolled at YVC or who graduated and/or transferred to a four-year institution, was consistently above 80 percent of participants (see Table 1), indicating that the program facilitated educational attainment. In 2019 and 2020, the Undergraduate Research Student Self-Assessment (URSSA) was incorporated into program assessment to evaluate self-reported student outcomes. The URSSA is modeled on the Student Assessment of Their Learning Gains instrument that is available for free public use (Student Assessment of Their Learning Gains n.d.) at www.salgsite.org and is intended for use by undergraduate research program administrators (Weston and Laursen 2015). Items from three constructs - "Thinking and Working Like a Scientist," "Personal Gains Related 
to Research Work," and "Skills" (see Table 2)-were completed by a STEM Pathway comparison group in the spring ( $n$ s $=28$ and 18, respectively, for 2019 and 2020) as well as 65 percent of YVC SURE participants after the program was finished ( $n \mathrm{~s}=20$ and 16 , respectively, for 2019 and 2020). The STEM Pathway comparison group consisted of students who had not yet participated in a research opportunity and who were eligible to apply for the YVC SURE program. The item preface was "How comfortable do you feel...," and a 6-point response scale from very uncomfortable (0) to very comfortable (6) was utilized. Cronbach's alphas for items in the three construct areas were $0.89,0.92$, and 0.93 , consistent with the ranges reported by Weston and Laursen (2015) who validated the URSSA in a sample of 3671 students across the United States and Canada.

Mean responses for items within each of the three constructs were calculated for each respondent. Response anonymity prevented matching responses between the STEM Pathway and SURE respondents; therefore, independent

\section{TABLE 2. URSSA Selected Items by Construct}

\section{Thinking and working like a scientist}

Analyzing data for patterns

Figuring out how to start a research project

Figuring out the next step in a research project

Problem-solving in general

Formulating a research question that could be answered with data Identifying limitations of research methods and designs

Understanding the theory and concepts guiding my research project Understanding the connections among disciplines

Personal gains related to research work

Confidence in my ability to contribute to science Comfort in discussing scientific concepts with others

Comfort in working collaboratively with others

Confidence in my ability to do well in future science courses

Ability to work independently

Developing patience with the slow pace of research

Understanding what everyday research work is like

Taking greater care in conducting procedures in the lab or field

\section{Skills}

Writing scientific reports or papers

Making oral presentations

Defending an argument when asked questions

Explaining my project to people outside my field

Preparing a scientific poster

Keeping a detailed lab notebook

Conducting observations in the lab or field

Using statistics to analyze data

Calibrating instruments needed for measurement

Working with computers and software

Understanding journal articles

Conducting database or Internet searches

Managing my time sample $t$ tests were utilized to analyze group differences. Overall, for the combined 2019 and 2020 URSSA data, compared to STEM Pathway students who had not participated in a research project, YVC SURE participants showed significantly greater mean responses on "Thinking and Working Like a Scientist" and "Personal Gains Related to Research Work" items, as well as a marginal trend for higher responses on "Skills" items (see Table 3). These findings occurred in the YVC SURE program despite the fact that the program required only about one-third of the time commitment of a standard URE.

\section{Mechanisms of Program Development and Success}

The YVC SURE program initially began through external funding from a partnership with a private, regional university; and funding from both institutional and community partnerships has been important in contributing to the longevity of the program. The success of the program was also heavily reliant on students and faculty who showed an interest in this opportunity. The sections below provide reflections on stakeholders who were important for this work and the mechanisms that have been vital to program development and success.

\section{Mechanism 1: Student Interest}

Undergraduate research has become a regular offering at YVC, and student interest appears to have stabilized across the years. In each of the last three summers, 30 to 40 applications were received, representing approximately 10 percent of STEM Pathway students. Student awareness of the YVC SURE program grew slowly but, in 2017, a multimedia marketing effort was initiated, employing websites, handouts, posters, emails, and face-to-face contact to increase the number of student applicants. These efforts were essential to improving awareness because, as previously noted, 83 percent of YVC students are first generation and likely do not know that college experiences can include research. In Yakima County, only 16 percent of households report earning a bachelor's or advanced degree, far below the state average of 37 percent. Thus, we feel that intentional campaigns to enhance awareness of the benefits of a research experience are a key component in stimulating student interest in research at two-year colleges.

Furthermore, many students completed projects oriented around the campus, community, or local region. Projects included analyzing student use of tutoring resources at YVC, measuring hygienic practices in local restaurants, evaluating local birdsong frequencies, and developing new technologies for local elementary students to experience STEM. These projects are tractable and are appealing to students seeking to connect their work with their community. In addition to the documented value of community-based research, URM students may be particularly motivated by projects with ties to their community (Ashford-Hanserd et al. 2020; Karukstis 2005). 
TABLE 3. Student Self-Assessment of URSSA Constructs after YVC SURE Relative to a Comparison Group

\begin{tabular}{|c|c|c|c|}
\hline \multirow{2}{*}{ URSSA ${ }^{\mathrm{a}}$ constructs } & \multicolumn{2}{|c|}{$\begin{array}{c}\text { Survey results } \\
\text { for combined } 2019 \text { and } 2020 \text { data } \\
\text { Mean (SD); 6-point scale }\end{array}$} & \multirow{2}{*}{$\begin{array}{l}\text { Statistical comparisons } \\
\text { between comparison } \\
\text { group and post-YVC } \\
\text { SURE }\end{array}$} \\
\hline & $\begin{array}{l}\text { STEM Pathway } \\
\text { comparison group } \\
(n=46)\end{array}$ & $\begin{array}{l}\text { Post-YVC SURE } \\
(n=36 ; 65 \% \\
\text { response rate })\end{array}$ & \\
\hline $\begin{array}{l}\text { Thinking and working } \\
\text { like a scientist }\end{array}$ & $\begin{array}{c}4.4(0.8) \\
\mathrm{CI}^{\mathrm{c}}=4.162,4.638\end{array}$ & $\begin{array}{c}5.0(0.5) \\
\mathrm{CI}=4.83,5.17\end{array}$ & $\begin{array}{c}t(80)=4.07 \\
p<0.001\end{array}$ \\
\hline $\begin{array}{l}\text { Personal gains related } \\
\text { to research work }\end{array}$ & $\begin{array}{c}4.8(0.7) \\
\mathrm{CI}=4.592,5.008\end{array}$ & $\begin{array}{c}5.1(0.5) \\
\mathrm{CI}=4.931,5.269\end{array}$ & $\begin{array}{c}t(80)=2.03 \\
p<0.05\end{array}$ \\
\hline Skills & $\begin{array}{c}4.5(0.8) \\
\mathrm{CI}=4.262,4.738\end{array}$ & $\begin{array}{c}4.8(0.6) \\
\mathrm{CI}=4.597,5.003\end{array}$ & $\begin{array}{c}t(80)=1.95 \\
p=0.05\end{array}$ \\
\hline
\end{tabular}

Note: ${ }^{a}$ Undergraduate Research Student Self-Assessment

${ }^{\mathrm{b}}$ Comparison group consisted of STEM Pathway students eligible for the YVC SURE who had not yet participated in research. The population size of STEM Pathway students who have not yet participated in research is unknown; therefore, a response rate cannot be calculated.

c95-percent Confidence Interval (CI)

\section{Mechanism 2: Faculty Buy-In}

Adding research responsibilities to faculty workload at a two-year institution has required the cooperation of multiple levels of college governance. Instructional supervisors, including a vice-president and deans, oversaw faculty workloads, and human resources managed contracts. YVC faculty are contractually obligated to fulfill their full-time workloads entirely by teaching, advising, and related committee work. Research is not mentioned in contracts. In addition, the majority of the faculty holds master's degrees as their terminal degree rather than PhDs. Thus, YVC faculty do not typically maintain research programs, because their skills are invested in the priorities of teaching and advising rather than research activities. Despite these limiting factors, program growth in faculty numbers as well as the high rate of faculty mentors returning to the program (see Table 1) was an essential element to the success of the program.

Several structural advantages in program design supported faculty buy-in. First, faculty with a strong desire for research could opt-into the program with little external pressure for those uninterested in becoming a research mentor. Second, summer teaching loads are lighter and more flexible than those in the regular academic quarter so that faculty could more easily add a few hours to each summer day for research. Third, in personal communication, faculty have commented that summer research is an opportunity to re-engage in their discipline and the cognitive process of doing science-an observation also documented by Osborn and Karukstis (2009). Fourth, research projects focused on the campus community also could contribute to curriculum development for the faculty mentors, allowing faculty to integrate research findings into their classroom work. Finally, faculty were incentivized to participate with a $\$ 3000$ stipend that was approximately three-quarters of the pay available for a standard fivecredit summer course.

\section{Mechanism 3: Partnerships with Universities}

Partnerships with four-year universities greatly increased YVC's capacity to support undergraduate research. First, faculty at four-year institutions who often maintain yearround research programs had a deep knowledge of discipline-specific opportunities that the YVC students and faculty could pursue. Second, the expectation of performing research among four-year university faculty typically motivates the pursuit of grants. YVC benefited when colleagues at regional four-year universities included funding for the YVC program to increase the pipeline of STEM students from two- to four-year institutions. As previously noted, the neighboring private, nonprofit Heritage University received a grant in 2011 that included start-up funding for YVC student research. In 2016, the nearest public four-year university, Central Washington University, also secured funding to partner with YVC. This partnership included support for research students and their mentors as well as campus visits and faculty-led science workshops. These collaborations had the additional benefit of building relationships among faculty at both institutions, providing a foundation for subsequent, multiple joint efforts to secure funding that could support student research.

\section{Mechanism 4: Partnerships with Community}

Community stakeholders have also been key to the program's success. YVC SURE research projects were supported by agricultural businesses, such as projects on quality assurance assessment of hop products, or projects 
requiring that farmers provide access to their apple orchards. Partnerships were formed with governmental organizations, such as the US Forest Service, US Department of Agriculture and the Washington State Department of Ecology, as well as with nongovernmental organizations such as the Nature Conservancy, Northwest Harvest, and the Cowiche Canyon Conservancy (a nonprofit land trust protecting the shrub-steppe habitat). These partnerships involve staff members from the partnering organization providing guidance on key questions, leading field trips, and engaging in lengthy discussions with students about the applicability of their results. In a few cases, these partnerships have led to financial commitments in which individual organizations have funded a student stipend or the continuation of a project further into the summer. Unfortunately, a sustainable financial model is not yet foreseen based on these contributions alone. From the perspective of a business owner or an agency director, funding students for a project is a commitment of finite resources that might be maximized with more conventional strategies like employment at minimum wage.

\section{Lessons Learned}

Multiple lessons can be learned from this experience that are applicable to other two-year institutions. First, the program does not mimic the standard URE common at four-year universities. This design was intentional. The financial burden of paying stipends to students and faculty for a research model of $30^{+}$hours per week for eight weeks would have substantially limited the number of students that could have been accommodated. Moreover, the program design meets the needs of many students who are balancing the demands of summer school, jobs, and family responsibilities. Second, the STEM faculty represent diverse disciplines with different approaches to research, and they have significant latitude in designing projects that are challenging and educationally fulfilling. Third, program assessment of student outcomes indicates educational achievements such as high continued enrollment at YVC, transfer and/or graduation rates, as well as self-reported increases in constructs such as "Thinking and Working Like a Scientist," "Personal Gains Related to Research Work," and "Skills."

Finally, YVC is an HSI that continues to adapt institutional practices from an "Hispanic-enrolling" institution to a "Hispanic-serving" institution. The "serving" spirit of an HSI-campus is multidimensional (Garcia, Núñez, and Sansone 2019), and YVC has primarily focused on educational metrics to monitor progress. As progress is made in reducing educational achievement gaps, there is much work to be done in nurturing student self-agency and helping Hispanic students identify their futures in STEM careers. Through a combination of one-on-one advising and multiple forms of advertising, high percentages of
URMs were enrolled in YVC's SURE. The future challenge is that this model of research still only serves a small fraction of YVC's STEM students; expanding opportunities for more students requires additional financial support and redesigning curriculum to increase the availability of course-based research experiences.

\section{Summary and Future Directions}

This article reviews the eight-year development process of an URE at a two-year college. Partnerships, particularly with regional universities, played a key role in securing funding. As further evidence of the value of partnerships, the authors of this article are a mix of personnel from two- and four-year institutions. YVC's SURE has greater stability because its partners are invested in the idea that UREs lead to student success and to greater transfer rates to four-year institutions. The partner institutions expand the ability to secure grant funding. Although the size of the program will likely vary due to fluctuations in funding, it seems highly probable that YVC SURE has a longterm future. Even the constraints imposed by the SARSCoV2 pandemic did not dim hopes. Faculty and students switched to online projects and persisted through summer 2020 , resulting in a successful online student symposium at the end of the program. YVC SURE will continue to adapt to logistic and financial hurdles so that as many students can be served as possible.

\section{Acknowledgments}

The authors would like to acknowledge the contributions of all SURE participants, faculty mentors, and community partners. YVC's SURE program developed under the leadership of Dean Kerrie Cavaness and Vice-President Tomás Ybarra and relied on support from NSF grants to Heritage University (1928570), Central Washington University (1356479), YVC (1564520), and the Pacific Northwest Consortium (1410465) in addition to Department of Education grants to Heritage University (P031C110182) and YVC (P031S130053 and P031C160075).

\section{References}

Ashford-Hanserd, Shetay, Kristy Daniel, Dana M. García, and Jenn L. Idema. 2020. "Factors That Influence Persistence of Biology Majors at a Hispanic-Serving Institution." Journal of Research in Technical Careers 4(1): 47-60. doi: 10.9741/25782118.1048

Attewell, Paul, Scott Heil, and Liza Reisel. (2012). "What Is Academic Momentum? And Does It Matter?" Educational Evaluation and Policy Analysis 34(1): 27-44. doi: 10.3102/0162373711421958

Bahr, Peter Riley, Christie Toth, Kathryn Thirolf, and Johanna C. Massé. 2013. "A Review and Critique of the Literature on Community College Students' Transition Processes and Outcomes in Four-Year Institutions." In Higher Education: Handbook of Theory and Research, edited by Michael B. Paulsen, 28: 459-511. London: Springer International Publishing doi: 10.1007/978-94007-5836-0_10 
Barber, Catherine R., John A. Palasota, Michelle A. Steiger, Ruth Ann Bagnall, Juan Carlos Reina, Jyoti Wagle, and Yiyan Bai. 2020. "Enhancing STEM Equity Programs with Action Research" Action Research, March: 1-18. doi: 10.1177/1476750320910491

Barney, Christopher C. 2017. "An Analysis of Funding for the NSF REU Site Program in Biology from 1987 to 2014.” Scholarship and Practice of Undergraduate Research 1(1): 11-19. doi: $10.18833 /$ spur/1/1/1

Carpi, Anthony, Darcy M. Ronan, Heather M. Falconer, and Nathan H. Lents. 2016. "Cultivating Minority Scientists: Undergraduate Research Increases Self-Efficacy and Career Ambitions for Underrepresented Students in STEM." Journal of Research in Science Teaching August: 1-26. doi: 10.1002/tea.21341

Cohen, Arthur M., Florence B. Brawer, and Carrie B. Kisker. 2014. The American Community College. 6th ed. San Francisco: Jossey-Bass.

Dinh, Trang V., and Yi Leaf Zhang. 2020. "Engagement in High-Impact Practices and Its Influence on Community College Transfers' STEM Degree Attainment." Соттиnity College Journal of Research and Practice 1-16. doi: $10.1080 / 10668926.2020 .1824133$

Eagan, M. Kevin Jr., Sylvia Hurtado, Mitchell J. Chang, Gina A. Garcia, Felisha A. Herrera, and Juan C. Garibay. 2013. "Making a Difference in Science Education: The Impact of Undergraduate Research Programs." American Educational Research Journal 50: 683-713. doi: 10.3102/0002831213482038

Espinosa, Lorelle. 2011. "Pipelines and Pathways: Women of Color in Undergraduate STEM Majors and the College Experiences That Contribute to Persistence." Harvard Educational Review 81(2): 209-241. doi: 10.17763/haer.81.2.92315ww157656k3u

Foley, Daniel, Lynn Milan, and Karen Hamrick. 2020. “The Increasing Role of Community Colleges among Bachelor's Degree Recipients: Findings from the 2019 National Survey of College Graduates." InfoBrief: National Center for Science and Engineering Statistics. Alexandria, VA: National Science Foundation. https://ncses.nsf.gov/pubs/nsf21309/

Garcia, Gina A., Anne-Marie Núñez, and Vanessa A. Sansone. 2019. "Toward a Multidimensional Conceptual Framework for Understanding 'Servingness' in Hispanic-Serving Institutions: A Synthesis of the Research." Review of Educational Research 89: 745-784. doi: 10.3102/0034654319864591

Goldrick-Rab, Sara. 2010. "Challenges and Opportunities for Improving Community College Student Success." Review of Educational Research 80: 437-469. doi: 10.3102/0034654310370163

Graham, Mark J., Jennifer Frederick, Angela Byars-Winston, Anne-Barrie Hunter, and Jo Handelsman. 2013. "Increasing Persistence of College Students in STEM." Science 341: 14551456. doi: $10.1126 /$ science. 1240487

Hernandez, Paul R., P. Wesley Schultz, Mica Estrada, Anna Woodcock, and Randie C. Chance. 2013. "Sustaining Optimal Motivation: A Longitudinal Analysis of Interventions to Broaden Participation of Underrepresented Students in STEM." Journal of Educational Psychology 105(1): 89-107. doi: 10.1037/a0029691

Hirst, Rachel A., Gilles Bolduc, Louis Liotta, and Becky WaiLing Packard. 2014. "Cultivating the STEM Transfer Pathway

28 Scholarship and Practice of Undergraduate Research and Capacity for Research: A Partnership between a Community College and a 4-Year College." Journal of College Science Teaching 43(4): 12-17. doi: 10.2505/4/jcst14_043_04_12

Horn, Laura, and Paul Skomsvold. 2011. "Web Tables - Community College Student Outcomes: 1994-2009.” NCES 2012-253 Department of Education. Accessed February 10, 2021. https:// nces.ed.gov/pubsearch/pubsinfo.asp?pubid=2012253

Karukstis, Kerry K. 2005. "Community-Based Research. A New Paradigm for Undergraduate Research in the Sciences." Journal of Chemical Education 82(1): 15-16. doi: 10.1021/ed082p15

Lopatto, David. 2017. "Undergraduate Research Experiences Support Science Career Decisions and Active Learning." CBE-Life Sciences Education 6: 297-306. doi: 10.1187/ cbe.07-06-0039

Lopez, Carlos, and Stephanie J. Jones. 2017. "Examination of Factors That Predict Academic Adjustment and Success of Community College Transfer Students in STEM at 4-Year Institutions." Community College Journal of Research and Practice 41: 168-182. doi: 10.1080/10668926.2016.1168328

Ma, Jennifer, and Sandy Baum. 2016. "Trends in Community Colleges: Enrollment, Prices, Student Debt, and Completion." College Board Research Brief 1-23. New York: The College Board.

Mooney, Geraldine M., and Daniel J. Foley. 2011. "Community Colleges: Playing an Important Role in the Education of Science, Engineering, and Health Graduates." NSF11-317. InfoBrief: National Center for Science and Engineering Statistics. Alexandria, VA: National Science Foundation.

National Science Board. 2012. Science and Engineering Indicators 2012. Arlington, VA: National Science Foundation.

Osborn, Jeffrey M., and Kerry K. Karukstis. 2009. "Benefits of Undergraduate Research, Scholarship, and Creative Activity." In Broadening Participation in Undergraduate Research: Fostering Excellence and Enhancing the Impact, edited by Mary K. Boyd, Jodi Lynn Wesemann, and Kimberley A. Frederick, 41-53. Washington, DC: Council on Undergraduate Research.

Russell, Susan H., Mary P. Hancock, and James McCullough. 2007. "The Pipeline. Benefits of Undergraduate Research Experiences." Science 316: 548-549. doi: 10.1126/science.1140384

Student Assessment of Their Learning Gains. n.d. "Welcome to the SALG Website for Instructors!” Accessed March 29, 2021. https://salgsite.net/

Van Noy, Michelle, and Matthew Zeidenberg. 2017. "Community College Pathways to the STEM Workforce: What Are They, Who Follows Them, and How?" New Directions for Community Colleges 178: 9-21. doi: 10.1002/cc.20249

Wang, Xueli. 2015. "Pathway to a Baccalaureate in STEM Fields: Are Community Colleges a Viable Route and Does Early STEM Momentum Matter?" Educational Evaluation and Policy Analysis 37: 376-393. doi: 10.3102/0162373714552561

Weston, Timothy J., and Sandra L. Laursen. 2015. "The Undergraduate Research Student Self-Assessment (URSSA): Validation for Use in Program Evaluation." CBE-Life Sciences Education 14: 1-10. doi: 10.1187/cbe.14-11-0206 


\section{Matthew R. Loeser}

Yakima Valley College, mloeser@yvcc.edu

Matthew R. Loeser is a faculty member in the Department of Life Sciences at Yakima Valley College and the project director of a Department of Education HSI-STEM award and a NSF S-STEM award.

Makaylah Newkirk is a data analyst in the Office of Institutional Effectiveness at Yakima Valley College who focuses on data specific to a HSI-STEM award from the US Department of Education.

Kara I. Gabriel is a professor in psychology at Central Washington University. Her primary research interests include cognitive biases, animal behavior, and experimental design.

Audrey D. Huerta is a professor in the geological sciences at Central Washington University. She is currently a National Science Foundation program director in the tectonics program.

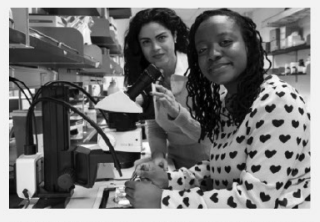

Recognizing and Valuing the Mentoring of Undergraduate Research, Scholarship, and Creative Activity by Faculty Members: Workload, Tenure, Promotion, and Award Systems

Janet A. Morrison, John F. Barthell, Anne Boettcher, David Bowne, Cheryl Nixon, Karen K. Resendes, and Julliane Strauss-Soukup

(UR) CUR White Paper No. 2

\section{Understand the strategic} educational position held by URSCA, the need for recognition of faculty mentorship, best practices for institutions, and the overall effect it may have with our knowledgeable CUR authors in this newly-released white paper.

\section{CUR.org/WHITEPAPERS}

Connect with us.

Share it with your friends. Let us know what you think. 